Brit. F. vener. Dis. (1972) 48, 350

\title{
Prevalence of yaws on Kar Kar Island, New Guinea
}

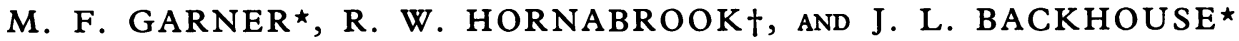 \\ From the ${ }^{\star}$ Institute of Clinical Pathology and Medical Research, Lidcombe, New South Wales, Australia, \\ and the +Institute of Human Biology, Goroka, Papua-New Guinea
}

The International Biological Programme has as one of its objectives the study of man's adaptation to his environment. With this in view the Australian Government, the Australian Academy of Science, and the Royal Society of England combined in a multi-disciplinary study of the population of Kar Kar Island, New Guinea. The organization of the projects studied and the field work were under the direction of the Institute of Human Biology, Papua-New Guinea (Hornabrook, 1970). One of the projects undertaken was to determine the prevalence of yaws in the Kar Kar population.

Kar Kar is a volcanic island which lies some 60 miles off the north coast of New Guinea immediately north-east of the town of Madang. It has a circumference of 60 miles and an area of 124 square miles. The population of approximately 17,000 is Melanesian and lives on the coastal slopes, the centre of the island being rugged, densely forested, and uninhabited. The economy is prosperous and depends on cocoa and coconut plantations. There is regular and frequent communication with Madang through pinnaces carrying copra to the mainland and an airstrip suitable for light aircraft. The island has been under the influence of several national groups-German, Australian, Japanese during the second world war, and finally Australian.

Kar Kar is divided roughly in half by two language groups of equal size-the Waskia and the Takia. Each group has remained separate, there being little intermarriage between the two.

Before the second world war, Kar Kar was described as the island of crooked men because of the severe deformities produced by infection with the yaws treponeme (Braun, 1968). After the war, yaws campaigns, first with arsenicals and later with penicillin, were carried out. Despite this, yaws still remained a problem.

In the International Biological Programme only one large village, Kaul, was studied in great depth

Received for publication February 14, 1972
(Hornabrook, 1970). Thus the majority of the sera in the treponemal survey came from Kaul, a Waskia village. In addition, sera were received from four other Waskia villages-Dorogodam, Langlang, Urara, and Mungar II-and from three Takia villagesDangsai, Katom, and Daup.

Each person from whom blood was taken had a complete clinical examination. Clinical signs of old yaws were found in 45 adults in the Waskia villages, the commonest signs being bowing of the tibia, deformities of the legs and feet, and loss of toes or feet. Less common findings were depressed nasal bridge, facial scars, deformed hands, loss of a leg following a large sore, and lesions around the knees. Clinically active secondary yaws was seen in ten Waskia children, who had lesions of the hands, legs, ankles, and feet, bowed tibiae, and lesions in the natal cleft. No cases of secondary or active yaws were encountered clinically among the people living in the Takia villages. The Takia side of the island has a Lutheran Mission hospital in its centre, while the Waskia side has none. No clinical evidence of syphilis was seen in the Waskia and Takia populations studied.

\section{Material and methods}

986 sera were received at the Institute of Clinical Pathology and Medical Research, Lidcombe, Australia, for treponemal antibody testing. The following tests were carried out on each serum: cardiolipin Wassermann reaction (CWR), Venereal Disease Research Laboratory (VDRL) slide test, Reiter protein complement-fixation (RPCF) test, Treponema pallidum immobilization (TPI) test, and fluorescent treponemal antibody absorption (FTA-ABS) test. A reactive TPI test result was taken to indicate yaws, and all other test results were compared with it.

\section{Results}

IN THE TOTAL GROUP STUDIED

Of 986 sera examined, 666 (67.5 per cent.) were reactive in the TPI test. There were 450 sera from 
males of which $333(74.0$ per cent.) gave a reactive TPI test result, and 536 from females, of which 333 (62.1 per cent.) were reactive in the TPI test.

Those under 15 years of age, who were considered to be children, comprised 24 per cent. of the group studied. Sera from 61.2 per cent of these children showed evidence of treponemal infection-145 out of 237 sera giving reactive results with the TPI test. Of 112 sera from boys 82 ( 73.2 per cent.) and of 125 sera from girls $63(50.4$ per cent.) were reactive in the TPI test. Of 749 sera from adults, 521 (69.6 per cent.) were reactive in the TPI test. Of 338 sera from males 251 ( 74.3 per cent.) and of 411 sera from females 270 ( 65.7 per cent.) were reactive in the TPI test and thus showed serological evidence of treponemal infection. The adults were divided into 15-year age groups. Details of TPI test reactivity by age and sex are given in Table I.
RESULTS IN EACH VILLAGE TESTED

The largest village tested was Kaul, 624 of the 986 sera received being from this area. Between 50 and 100 sera were tested from four of the seven other villages surveyed and under 50 sera from the remaining three villages.

Over 75 per cent. of the sera from the Waskia villages of Kaul, Langlang, and Urara showed reactive TPI test results. Similar results were found in the sera from the males in these villages, the figures for the females being slightly lower (Table II). Between 40 and 60 per cent. of the sera from Dorogodam, Dangsai, and Mungar II showed evidence of treponemal infection, as did 29.8 per cent. of those from Katom. In only one village, Daup, were less than 20 per cent. of the sera reactive in the TPI test. The results for males and females were comparable. Details are given in Table II.

TABLE I TPI test results in relation to age and sex in population studied

\begin{tabular}{|c|c|c|c|c|c|c|c|c|c|}
\hline \multirow{3}{*}{$\begin{array}{l}\text { Age } \\
(y r s)\end{array}$} & \multirow{3}{*}{$\begin{array}{l}\text { No. of } \\
\text { sera } \\
\text { tested }\end{array}$} & \multicolumn{2}{|c|}{ TPI-reactive } & \multicolumn{3}{|l|}{ Males } & \multicolumn{3}{|c|}{ Females } \\
\hline & & \multirow{2}{*}{ No. } & \multirow{2}{*}{ Per cent. } & \multirow{2}{*}{$\begin{array}{l}\text { No. of } \\
\text { sera } \\
\text { tested }\end{array}$} & \multicolumn{2}{|c|}{ TPI-reactive } & \multirow{2}{*}{$\begin{array}{l}\text { No. of } \\
\text { sera } \\
\text { tested }\end{array}$} & \multicolumn{2}{|c|}{ TPI-reactive } \\
\hline & & & & & No. & Per cent. & & No. & Per cent. \\
\hline $\begin{array}{l}\text { Total } \\
\text { children } 0-14\end{array}$ & 237 & 145 & $61 \cdot 2$ & 112 & 82 & $73 \cdot 2$ & 125 & 63 & $50 \cdot 4$ \\
\hline $15-29$ & 339 & 201 & $59 \cdot 3$ & 136 & 86 & $63 \cdot 2$ & 203 & 115 & $56 \cdot 7$ \\
\hline $45-59$ & 127 & 95 & $74 \cdot 8$ & 58 & 46 & $79 \cdot 3$ & 72 & 50 & $69 \cdot 4$ \\
\hline $60+$ & 45 & 28 & $62 \cdot 2$ & 27 & 18 & $66 \cdot 7$ & 18 & 10 & $55 \cdot 6$ \\
\hline $\begin{array}{l}\text { Total } \\
\text { adults }\end{array}$ & 749 & 521 & $69 \cdot 6$ & 338 & 251 & $74 \cdot 3$ & 411 & 270 & $65 \cdot 7$ \\
\hline
\end{tabular}

TABLE II Number and percentage of TPI-reactive sera in each village, by sex

\begin{tabular}{|c|c|c|c|c|c|c|c|c|c|}
\hline \multirow{3}{*}{ Village } & \multirow{3}{*}{$\begin{array}{l}\text { No. of } \\
\text { sera } \\
\text { tested }\end{array}$} & \multicolumn{2}{|c|}{ TPI-reactive } & \multicolumn{3}{|l|}{ Males } & \multicolumn{3}{|l|}{ Females } \\
\hline & & \multirow{2}{*}{ No. } & \multirow{2}{*}{ Per cent. } & \multirow{2}{*}{$\begin{array}{l}\text { No. of } \\
\text { sera } \\
\text { tested }\end{array}$} & \multicolumn{2}{|c|}{ TPI-reactive } & \multirow{2}{*}{$\begin{array}{l}\text { No. of } \\
\text { sera } \\
\text { tested }\end{array}$} & \multicolumn{2}{|c|}{ TPI-reactive } \\
\hline & & & & & No. & Per cent. & & No. & Per cent. \\
\hline Kaul & 624 & 476 & $76 \cdot 3$ & 272 & 230 & $84 \cdot 6$ & 352 & 246 & $69 \cdot 9$ \\
\hline Dorogodam & 61 & 36 & $59 \cdot 0$ & 26 & 17 & $65 \cdot 4$ & 35 & 19 & $54 \cdot 3$ \\
\hline Langlang & 56 & 43 & $76 \cdot 8$ & 28 & 21 & $75 \cdot 0$ & 28 & 22 & $78 \cdot 6$ \\
\hline Urara & 55 & 45 & $81 \cdot 8$ & 24 & 23 & $95 \cdot 8$ & 31 & 22 & $71 \cdot 0$ \\
\hline Mungar II & 70 & 28 & $40 \cdot 0$ & 38 & 20 & $52 \cdot 6$ & 32 & 8 & $25 \cdot 0$ \\
\hline Daup & 37 & 5 & $13 \cdot 5$ & 24 & 4 & $16 \cdot 7$ & 13 & 1 & $7 \cdot 7$ \\
\hline Dangsai & 36 & 19 & $52 \cdot 8$ & 16 & 10 & $62 \cdot 5$ & 20 & 9 & $45 \cdot 0$ \\
\hline Katom & 47 & 14 & $29 \cdot 8$ & 22 & 8 & $36 \cdot 4$ & 25 & 6 & $24 \cdot 0$ \\
\hline Total & 986 & 666 & $67 \cdot 5$ & 450 & 333 & $74 \cdot 0$ & 536 & 333 & $62 \cdot 1$ \\
\hline
\end{tabular}


RESULTS IN THE CHILDREN AND ADULTS IN EACH villaGE (Table III)

In Kaul, Langlang, and Urara over 70 per cent. of sera from both children and adults showed reactive TPI tests. Sera from children in Dorogodam showed 35.7 per cent reactivity and sera from children in Mungar II showed 10 per cent. compared with 65.9 and 52 per cent. respectively of the sera from the adults from these villages. In Daup more children than adults showed serological evidence of treponemal infection, but a total of only 37 sera from both adults and children were tested. The sera from children in Dangsai and Katom were too few for the results to be significant.
RESULTS IN CHILDREN, BY SEX, IN EACH VILLAGE (Table IV)

Of the 237 sera from children, 155 came from Kaul, and $116(74.8$ per cent.) gave reactive results in the TPI test. Sera from 61 (89.7 per cent.) of the 68 male children tested showed reactive TPI test results; the figures for the female children were $55(63 \cdot 2$ per cent.) out of 87. In the remaining villages sera from between one and twenty children only were tested. Over 75 per cent. of the male children in Urara, Dorogodam, and Langlang showed serological evidence of treponemal infection; the figures for the female children were $50,11 \cdot 1$, and $66 \cdot 6$ per cent. respectively. In Daup, sera from eight female

TABLE II I Number and percentage of TPI-reactive sera in children and adults in each village

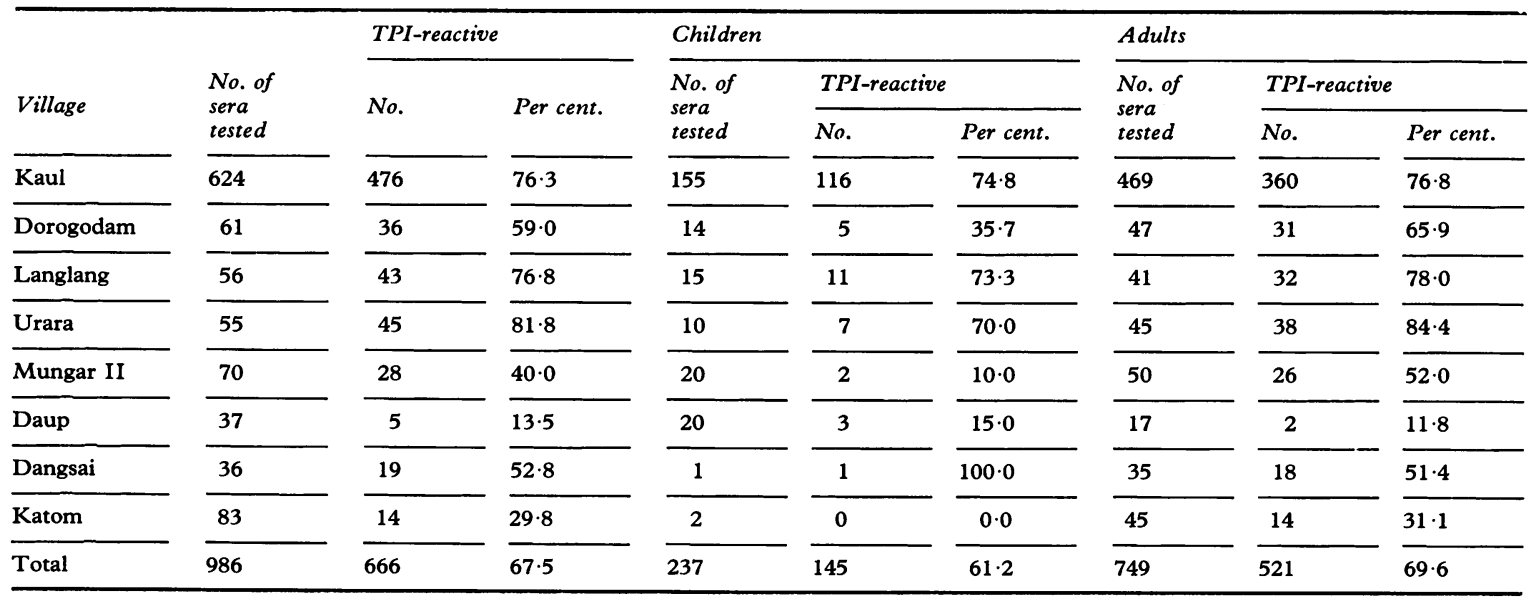

TABLE IV Number and percentage of TPI-reactive sera in children, bv sex, in each village

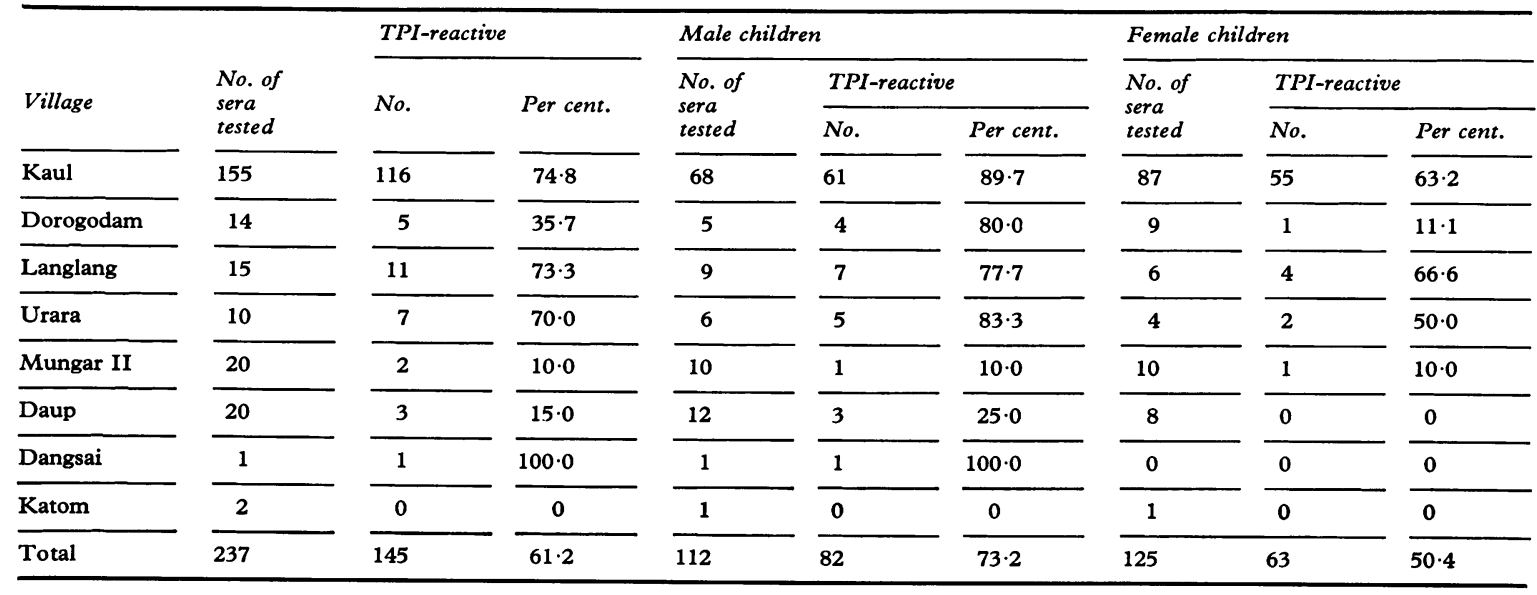


children were tested, and all were negative, but sera from three out of twelve male children in this village were reactive in the TPI test. The numbers from Dangsai and Katom were too few to be considered.

RESULTS IN THE LANGUAGE GROUPS

The test results in the Waskia and Takia language groups were as follows:

\begin{tabular}{|c|c|c|}
\hline Villages & W'askia & Takia \\
\hline $\begin{array}{l}\text { Total no. of sera tested } \\
\text { TPI-reactive } \quad \text { No. } \\
\\
\text { Per cent. }\end{array}$ & $\begin{array}{l}866 \\
628 \\
72 \cdot 5\end{array}$ & $\begin{array}{c}120 \\
38 \\
31 \cdot 7\end{array}$ \\
\hline $\begin{array}{ll}\text { No. of adult sera tested } \\
\text { TPI-reactive } & \begin{array}{l}\text { No. } \\
\text { Per cent. }\end{array}\end{array}$ & $\begin{array}{l}652 \\
487 \\
74 \cdot 7\end{array}$ & $\begin{array}{c}97 \\
34 \\
35 \cdot 1\end{array}$ \\
\hline $\begin{array}{l}\text { No. of sera tested from } \\
\text { children } \\
\text { TPI-reactive } \\
\begin{array}{ll}\text { No. } \\
\text { Per cent. }\end{array}\end{array}$ & $\begin{array}{l}214 \\
141 \\
65 \cdot 9\end{array}$ & $\begin{array}{c}23 \\
4 \\
17 \cdot 4\end{array}$ \\
\hline
\end{tabular}

COMPARISON OF TEST RESULTS

The TPI test was regarded as the most specific test for treponemal infection for the purposes of this survey (Wilkinson and Rayner, 1966), and the results of all other tests were compared with it.

The numbers of sera found reactive in each test were:

TPI-666;

FTA-ABS-649;

CWR-283;

RPCF-492;

VDRL-532.

There were 245 sera which were reactive in all five tests, and in all, 28 different combinations of reactive test results occurred.

Apart from the sera which were reactive in all five tests, the most frequently occurring combinations of reactive test results were:

VDRL, FTA-ABS, and TPI (149);

VDRL, RPCF, FTA-ABS, and TPI (81);

RPCF, FTA-ABS, and TPI (72);

FTA-ABS, and TPI (69).

The FTA-ABS test was non-reactive in eight sera in which the other four tests were reactive. In five sera only the TPI test was reactive. The TPI test was non-reactive in nine sera in which the FTA-ABS test was reactive; the results in these nine sera were: CWR, RPCF, VDRL, and FTA-ABS reactive in 7; CWR, VDRL, and FTA-ABS reactive in 1; CWR, RPCF, and FTA-ABS reactive in 1.
The FTA-ABS test result was classed as doubtful in 57 sera, which showed a $1+$ fluorescence. In 33 of these sera the FTA-ABS was the only test to give a result other than non-reactive, in eighteen the RPCF test was also reactive, in five the VDRL test was reactive, and in one the CWR was reactive.

Biological false positive (BFP) reactions were shown by 48 sera, in all of which both the TPI and FTA-ABS test results were non-reactive. The BFP reactions occurred as follows:

VDRL-11;

CWR-2;

CWR and VDRL-2;

CWR, VDRL, and RPCF-1;

RPCF-28;

VDRL and RPCF-3;

CWR and RPCF-1.

Sera from 31 children and 22 adults showed CWR titres of $40,80,160$, or 320 , and/or VDRL test titres of 8,16 , or 32 . All of these sera gave reactive TPI test results.

\section{Discussion}

There was a marked difference in the prevalence of clinical and serological yaws in the Kar Kar population studied. There were only 55 out of 986 people ( 5.6 per cent.) who showed clinical evidence of yaws, either active or old infections, but serologically the prevalence of yaws, as judged by the TPI test result, was 67.5 per cent. As expected in areas where yaws is endemic, the prevalence in males was higher than in females.

The prevalence of yaws in the children, who comprised 24 per cent. of the total number tested, differed little from that in the adults. Males, whether children or adults, showed an almost identical prevalence. In female children the prevalence was noticeably less than in female adults- 50.4 per cent. compared with 65.7 per cent. The age group with the highest prevalence was 30 to 44 years in both males and females, the rates being 84.6 and 80.5 per cent. respectively. In no age group in either sex did the rate fall below 50 per cent.

The highest prevalence of yaws in the total group and in children and adults was found in the Waskiaspeaking villages of Kaul, Langlang, and Urara, where the prevalence rates were over 70 per cent. Of the eight villages tested, only one, Daup, showed a prevalence rate below 20 per cent.

The figures for the children in the Takia villages of Dangsai and Katom must be ignored as too few were tested. In some villages there was less serological evidence of yaws in the children than in the adults. This may or may not be significant, as in the villages 
concerned only seventy people or under were tested, twenty or less being children.

Sera from the ten children in the survey who showed signs of clinically active secondary yaws all had titres in the CWR of 160 or 320 and in the VDRL test of 16 or 32 . They were aged 10 to 12 years and came from the villages of Kaul, Langlang, and Urara. There were another 31 children whose sera had CWR titres of 80,160 , or 320 and/or VDRL test titres of 8,16 , or 32 . These children came from Kaul, Urara, and Dorogodam, and were aged from 9 to 14 years; none showed any clinical evidence of yaws. The TPI test was reactive in the sera of all 41 children.

Sera from 22 adults, whose TPI test results were reactive, showed CWR titres of $40,80,160$, or 320 and/or VDRL test titres of 8,16 , or 32 . Only three of these adults, who were aged 22, 27, and 39 years respectively, showed clinical signs of old yaws infection. These 22 adults were aged from 15 to 56 years, sixteen being under 30 years of age. They were probably suffering from early latent and latent yaws. Clinical signs of old yaws were seen in 45 adults, sera from 42 of them having low-titre CWR and VDRL test results. This is to be expected in a long-standing treponemal infection, in which the CWR and VDRL test titres fade naturally with time even without treatment. Yaws and syphilis are indistinguishable serologically, but as there was no clinical evidence of syphilis in the population studied and active clinical yaws was found to be present, the possibility that the children and adults with high titre serology and no clinical evidence of either disease were infected with syphilis, was considered to be remote.

The most significant figures in the survey were probably those from Kaul village, where sera from approximately one-third of the inhabitants were tested. The prevalence rates for yaws in Kaul were: Total group studied 76.3 per cent., males 84.6 and

females 69.9 per cent;

total children $\mathbf{7 4 . 8}$ per cent;

total adults 76.8 per cent;

male children $89 \cdot 7$ per cent.;

female children 63.2 per cent.

Of the ten children who showed clinical evidence of active secondary yaws, six were from Kaul village. A further 24 children (11 boys and 13 girls), who showed no clinical evidence of yaws, but whose sera gave high-titre test results as discussed above, came from Kaul. Thus thirty of the $116 \mathrm{Kaul}$ children whose sera were reactive in the TPI test had serological results which suggested an active stage of yaws, yet only six of them showed any clinical evidence of infection.
There are obviously active reservoirs of yaws infection among the children on Kar Kar. In three villages (Kaul, Langlang, and Urara), this is seen clinically and serologically, and in another village (Dorogodam) it is evident only from the high-titre serological test results.

This raises the question whether yaws is changing clinically. Have most people in communities where yaws is endemic now developed a resistance to clinical signs of the infection? In the Kar Kar population the serological pattern of the disease does not appear to have altered. Is yaws behaving more like syphilis in its early stages in that it is able to pass clinically undetected ? Or is this a gradual change in the behaviour of an organism which in the foreseeable future will disappear as the cause of an endemic disease and reappear or be replaced by a similar organism causing a sporadic disease, i.e. syphilis. Because syphilis and yaws are indistinguishable serologically, diagnosis has always depended on clinical signs. If the present situation continues it will pose considerable diagnostic and social problems in the future in developing areas where gradually the endemic treponemal diseases will disappear and be replaced by syphilis.

There was a significant difference in the serological prevalence of yaws in the two language groups, that in the Takia being less than half that in the Waskia. The Takia side of the island, while being in every way similar to the northern Waskia side, has a Lutheran Mission Hospital in its centre. Consequently there has been a good deal more therapeutic intervention for cases of yaws in the vicinity of the hospital. Previous yaws campaigns have been designed to cover the whole island, but the Takia area close to the hospital has received not only the benefit of anti-yaws campaigns, but more intensive treatment between campaigns. The Waskia population is remote from the hospital and therefore less likely to seek its aid. This is the probable explanation of the difference in the amount of serological yaws found in the two sections of the island.

In this survey the TPI test was the most useful one for the diagnosis of treponemal infection. The VDRL test was as useful as the CWR in determining high-titre seroreactivity.

Despite several anti-yaws treatment campaigns on Kar-Kar in the past, there are obviously reservoirs of active infection in the inhabitants especially among the children. Mass treatment of the population with a long-acting penicillin is again indicated to help banish yaws from 'the island of crooked men'.

\section{Summary}

Kar Kar is an island off the north-east coast of New 
Guinea, where yaws has been a problem for many years despite several treatment campaigns. As part of the International Biological Programme, 986 sera were examined from the inhabitants for evidence of treponemal infection. A reactive TPI test result was taken to indicate yaws infection.

The prevalence of yaws in the total population studied was found to be 67.5 per cent. Children under 15 years of age made up 24 per cent. of the total number tested, and sera from 61.2 per cent. of them were reactive in the TPI test.

There were 45 adults who showed clinical evidence of old yaws and ten children who had clinically active secondary yaws. In addition, a further 31 children had no signs of clinical yaws but their sera gave high-titre CWR and VDRL test results. This raises the question whether, in some populations, yaws is becoming like syphilis and passing unnoticed clinically in its early stages.

As there are areas where active infection exists, mass treatment of the whole population is indicated.

This work was assisted in part by a grant from the World Health Organization.

\section{References}

Braun, T. (1968) Personal communication

Hornabrook, R. W. (1970) S. Pacif. Bull., 20, No. 1, p. 15
Wilkinson, A. E., and Rayner, C. F. A. (1966) Brit. F. vener. Dis., 42, 8

La prévalence du pian dans l'lle de Kar Kar, Nouvelle Guinée

SOMMAIRE

Kar Kar est une île au large de la côte nord-est de la Nouvelle Guinée où le pian a été un problème depuis de nombreuses années, malgré plusieurs campagnes de traitement. Dans le cadre de l'International Biological Programme, 986 sérums furent prélevés dans la population et examinés pour mettre en évidence une infection tréponémique. Un résultat positif du TPI fut considéré comme traduisant une infection pianique.

Dans l'ensemble de la population étudiée, la prévalence du pian fut trouvée à 67,5 pour cent. Les sérums des enfants au-dessous de 15 ans représentaient 24 pour cent du nombre total des sérums examinés et, parmi eux, 61,2 pour cent étaient positifs au TPI.

On trouva 45 adultes avec des signes cliniques de pian ancien et 10 enfants avec des signes de pian secondaire cliniquement actif. En outre, 31 autres enfants ne présentaient pas de signes cliniques de pian mais leur sérum était positif à un haut titre pour la réaction de Wassermann et le test VDRL. Ceci pose la question de savoir si, dans quelques groupes de population, le pian n'est pas en train de devenir semblable à la syphilis, avec des stades précoces qui passent cliniquement inaperçus.

Comme il y a des zones où l'infection est en activité, le traitement de masse de toute la population est indiqué. 